

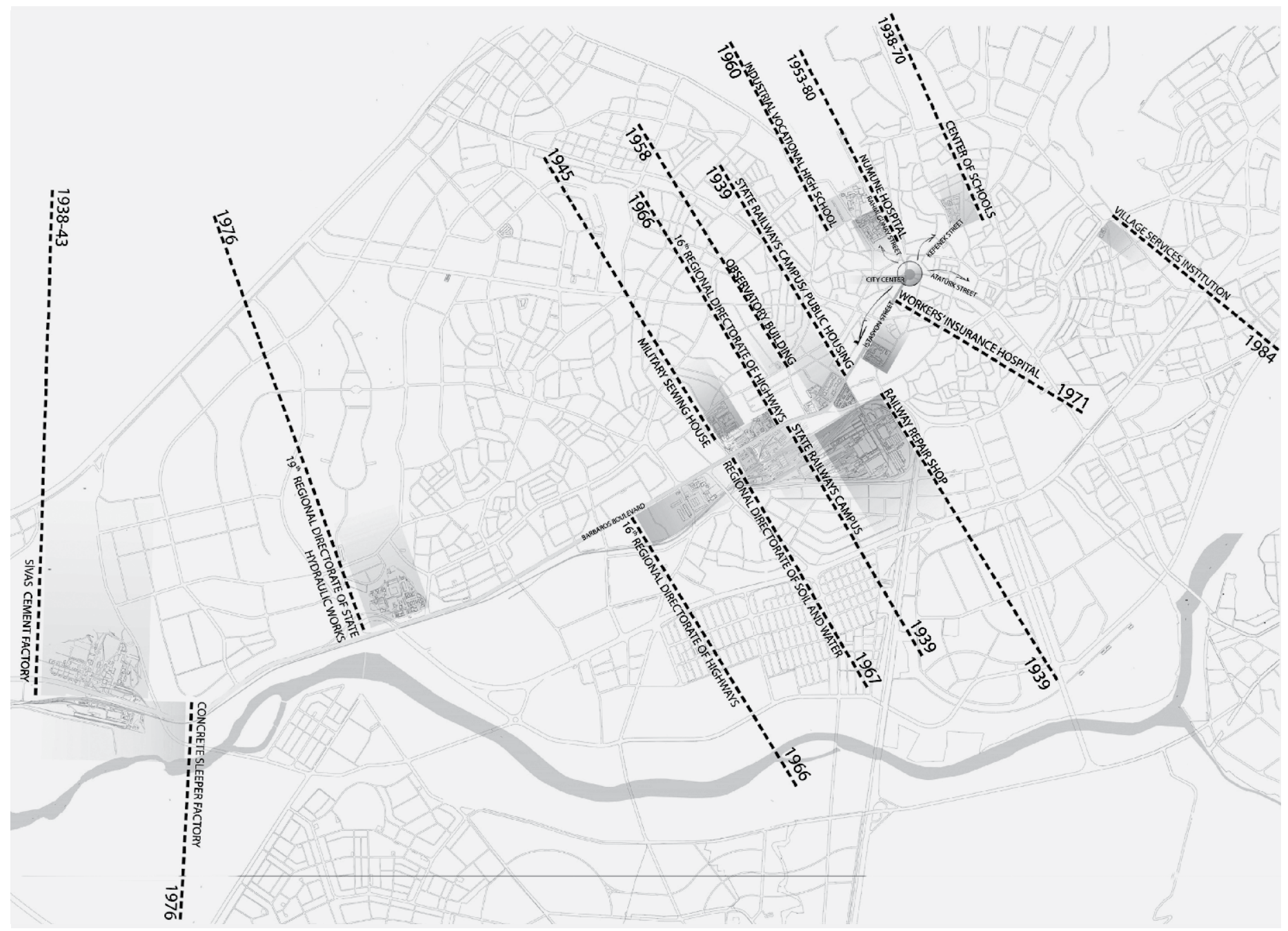

FIG. 1 LOCATION OF MODERN PUBLIC BUILDINGS, BUILT BETWEEN 1930-1980 SL. 1. LOKACIJA MODERNISTICEKIH JAVNIH ZGRADA IZGRADENIH IZMEĐU 1930. I 1980. 


\section{PINAR Koç}

CUMHURIYET UNIVERSITY

Faculty of ARCHITECTURe, Fine Arts ANd Design

DEPARTMENT OF ARCHITECTURE

TURKEY - 58140 SIVAS, CUMHURIYET ÜNV. 61

pinarkoc85@gmail.com

Scientific Subject Review

https://doi.org/10.31522/p.28.1(59).7

UDC 725:72.036 (560 SIVAS) "19"

Technical Sciences / Architecture and Urban Planning

2.01.04. - HISTORY AND THEORY OF ARCHITECTURE and Preservation of the Built Heritage

ARticle Received / AcCepted: 17. 2. 2020. / 23. 6. 2020.
SVEUĊILIŠTE CUMHURIYET

FAKULTET ZA ARHITEKTURU, LIKOVNE UMIETNOSTI I DIZAIN

ODSIEK ZA ARHITEKTURU

TURSKA - 58140 SIVAS, CUMHURIYET ÜNV. 61

pinarkoc85@gmail.com

PREgLEDNI ZNANSTVENI ČLANAK

https://doi.org/10.31522/p.28.1(59).7

UDK 725:72.036 (560 SIVAS) "19"

TEHNIĊKE ZNANOSTI / ARHITEKTURA I URBANIZAM

2.01.04. - POVIJEST I TEORIJA ARHITEKTURE

ZZAŠTITA GRADITELJSKOG NASLIJEDA

CLLANAK PRIMLJEN / PRIHVACEN: 17. 2. 2020. / 23. 6. 2020

\title{
Modern Public Buildings in Sivas AND THEIR ARCHITECTURAL ANALYSIS
}

\author{
ANALIZA ARHITEKTURE MODERNE \\ NA PRIMJERIMA JAVNIH ZGRADA U SIVASU
}

FACTORY

MODERNIZATION PRACTICE

PUBLIC BUILDINGS

REPUBLICAN PERIOD

SIVAS, TURKEY

With the proclamation of the Republic in 1923, Turkey began to experience modernization. Sivas as an Anatolian city has its own regional modernization practice in parallel with the nation-state modernization. Between the period of 1930-1950, Sivas was developed by factories and after the 1950s, public buildings with campuses were added to the modern city. As a consequence, city morphology expanded to the south and west and the traditional-modern dilemma became evident in the urban area.

\author{
TVORNICA \\ PRAKSA MODERNIZACIJE \\ JAVNE ZGRADE \\ RAZDOBLJE REPUBLIKE \\ SIVAS, TURSKA
}

Proglašenjem Republike 1923. godine Turska je krenula putem modernizacije. Anatolijski grad Sivas prolazi kroz vlastitu praksu regionalne modernizacije usporedno s nacionalno-državnom modernizacijom. Između 1930. i 1950. godine grad se industrijski razvio, a nakon 50-ih godina 20. stoljeca izgrađene su javne zgrade. Posljedično, grad se u morfološkom smislu proširio prema jugu i zapadu, dok je u urbanim područjima došla do izrażaja dilema u pogledu odnosa tradicionalnoga i modernoga. 


\section{INTRODUCTION ${ }^{1}$}

\author{
UVOD
}

his text aims to analyze modernization practice in Sivas from the 1930 s to 1980 s. It should be mentioned that modernization practice in Sivas is characterized by public buildings and factories. Thus, the main problem framework here is how public buildings and factories have contributed to the transformation of urban and architectural dynamics. At this point, it should be briefly bracketed that modernization practices in Sivas and Turkey are affected by the Modern Movement in the world context. According to Frampton ${ }^{2}$, it is difficult to determine the beginning of the modern period. However, by the midnineteenth century, there was a demand for new architecture and this period is marked as the transition. As Collins ${ }^{3}$ stated, architecture was faced with new standards of construction, new materials, new needs that had not existed a century before. Thus, all achievements of industry and modernization process are directly reflected in the cities by architectural dynamics and new planning concepts. By the beginning of the $20^{\text {th }}$ century, functionalism and rationalism emerged as a new architectural style in parallel with the Modern Movement and modernization process. This comprises of usage of reinforced concrete, steel and glass as the construction material, cubic forms and cartesian grids as design principles, as well as the exclusion of the decoration, stylistic ornaments and other traditional details. ${ }^{4}$ In a wider concept, this process is seen as a whole and referred to as an international style. However, it should not be overlooked that there are some differences, disjunctions, ruptures and localities in terms of modernization practice. Jencks ${ }^{5}$ suggests a pluralism and postulates a series of discontinuous movements in recent architecture. On the other hand, this Eurocentric modernization conception has faced critical approaches after World War II and some narratives such as synchronic and diachronic, have emerged. When it is evaluated in this context, it should be stated that diachronic narratives for modern architecture mark otherness. Although some countries do not internalize the modernity conditions with their western connotations, Modern Movement, modernism, and modernization are transferred to these countries by other dynamics. One such dynamic is the nation-state concept. As Bozdoğan and $A_{k c a n}{ }^{6}$ stated, rationalist/functionalist progressivism of modern architecture and urbanism is embraced by revolutionary regimes and legitimized as active agents of modernity. In this respect, Turkey as a nation-state aimed to develop comprehensive spatial strategies after the 1930 in relation to modernism. This program refers to the diachronic conception of western modernism although it does not internalize modernity conditions.

Ankara is the capital city of the new nationstate and it is the first experimental area of comprehensive modernization program in terms of western modernism sources. At this point, Ankara is the center and headquarters of the spatial strategies of the nation-state. Namely, Ankara is the first city in Turkey where the rational architecture of modernism is seen and thus, it is accepted as a model for the other Anatolian cities. In this respect, spatial constituents of modernism have expanded to other Anatolian cities over time. Here again, there emerged a diachronic narrative of modernism. Sivas as a peripheral city takes Ankara as a reference. Ankara is directly formed by modernization practice of the nation-state. It can be stated that there is a conscious modernization practice in Ankara. However Sivas does not have such an impact. Rather than conscious modernization, Sivas experienced modernization practice through stimulus conditions and this revealed an artificial modernity. What makes Sivas important in modernization practice is that modernization is imported by the nation-

1 This study is derived from doctoral thesis, titled 'An Analysis on the Stratums of Modernization Trace Between the Range of 1870-1970 in Sivas: A Model Proposal for Spatial and Periodical Discrimination' conducted at Necmettin Erbakan University, the Graduate School of Natural and Applied Science, Department of Architecture.

2 FRAMPTON, 1992: 8

3 ColLINS, 1998: 206

4 BozdoĞAN, 2008: 16

5 JENCKS, 1985: 13

6 BozdoĞAN, AKCAN, 2012: 19 
state and by embracing the modernist aesthetic artificially. The city gained contradiction and complexity between traditional texture and the modern one. Also, this situation has contributed to understanding diachronic modernization more clearly among the plural modernity narratives.

Although it is emphasized that the modernization program implemented by the founding cadres of the Republic is often seen as an authoritarian approach, this also shows an orientation that manipulates rational transformations in urban space. A modernization practice that involves not only the modernization of the state, but also the modernization of society by undertaking the task of destroying the attitude of traditionalism. On the other hand, it is designed to replace the old with the appropriate rules of this track and to train new generations according to the requirements of this track. ${ }^{7}$ In other words, the idea of a nation-state, which ensures the consolidation of modern institutions, has to realize a "civilized" imagination. According to Berman $^{8}$, in countries where the modernization process has not found itself, modernism has to be nourished by dreams, not social reality. Thus, the architectural expression of the modernization programs implemented by the ruling elites of the nation-states emerged as "the civilization mission". ${ }^{9}$

More specifically, the founding ideology of the Republic defines the concept of progress which it uses to reach the level of Western civilization in the context of technical and economic development. ${ }^{10}$ In this context, factories, which are the basis of industrialization, play an important role in transforming urban space and society. On the other hand, the state was an important entrepreneur in the factories established after the 1930 s due to the burdens of the War of Independence and the world economic depression of 1929 . For example, Sümerbank, responsible for the industry, and Etibank, responsible for mining, were established in 1933. These institutions supported all kinds of initiatives that contributed to the development of state enterprises. ${ }^{11}$ These entrepreneurial imaginations of the period revealed the formation of the social classes by the state, the development of the new regime identity, the definition of the citizen, and the discourses of industrialization

\footnotetext{
7 BERKES, 2002: 522

8 BERMAN, 2017: 315-316

9 BozDoĞAN, 1999: 122

10 GÜLALP, 1999: 50

11 ZÜRCHER, 2002: 288

12 CengizKan, 2009: 256

13 SARGIN, 2017: 30

14 BATUMAN, 2017: 44

15 TEKELI, 1998: 12

16 AKPINAR, 2010: 12
}

and modernization which were carried out in parallel with nationalization. ${ }^{12}$

The economic, technical, and social mechanisms created by the factories have been carried out simultaneously with the redefinition of publicity in urban space. In a sense, the factories, equipped with the rationality of modernism, played a founding role in changing the form of publicity and public structures. According to Sarg $\mathrm{In}^{13}$, unlike the fragmented public space organization based on the congregational system of the Ottoman period, there is a central-periphery relationship that was designed all over again with republican ideology. The effectiveness of public spaces on an urban scale has thus transferred a mechanism parallel to modernization of the city. Public space has become a tool in which social power relations are established and carried. ${ }^{14}$ After 1950, modernization practice had begun to be implemented sensitively to populist tendencies; with the discourse of liberalization, the economy of the country began to expand and the importance given to the private sector increased. ${ }^{15}$ According to Akpınar ${ }^{16}$, the 1950 s visualized modernism and the distancing of the country from an inward and nationalist understanding.

The discovery of such a mechanism within the scope of this text will be discussed in the Sivas scale (Fig. 1). The text will be shaped on three basic axes. The first of these will be the examination of the state railways campus where the imaginary content and the representative dynamics of the early Republican ideology are instrumentalized. In addition, the urban-spatial activity and effects of the settlement, which reflects the prestige of modernism in terms of urban scale to the western part of the city, away from the traditional core of the city, will be analyzed. The second research axis will be the examination of transformations in the new industrial zone on the western side of the city until the $1950 \mathrm{~s}$ and their comparison with the modern public buildings that have penetrated the traditional fabric. Finally, the leaps created by the changing conditions in the public pattern after 1950 will be studied.

\section{PRIORI IMAGINARY TOOLS OF MODERNISM IN URBAN SPACE: SIVAS STATE RAILWAYS CAMPUS AND RAILWAY REPAIR SHOP}

\section{ALATI MODERNIZACIJE GRADSKOG PROSTORA: DRŽAVNA ŽELJEZNICA U SIVASU I POSTROJENJE ZA REMONT ŽELJEZNICE}

Urban renewal movements in Sivas, which started in the second half of the $19^{\text {th }}$ century, were mostly evident via architectural changes after 1913 and as a result, stylistic changes 

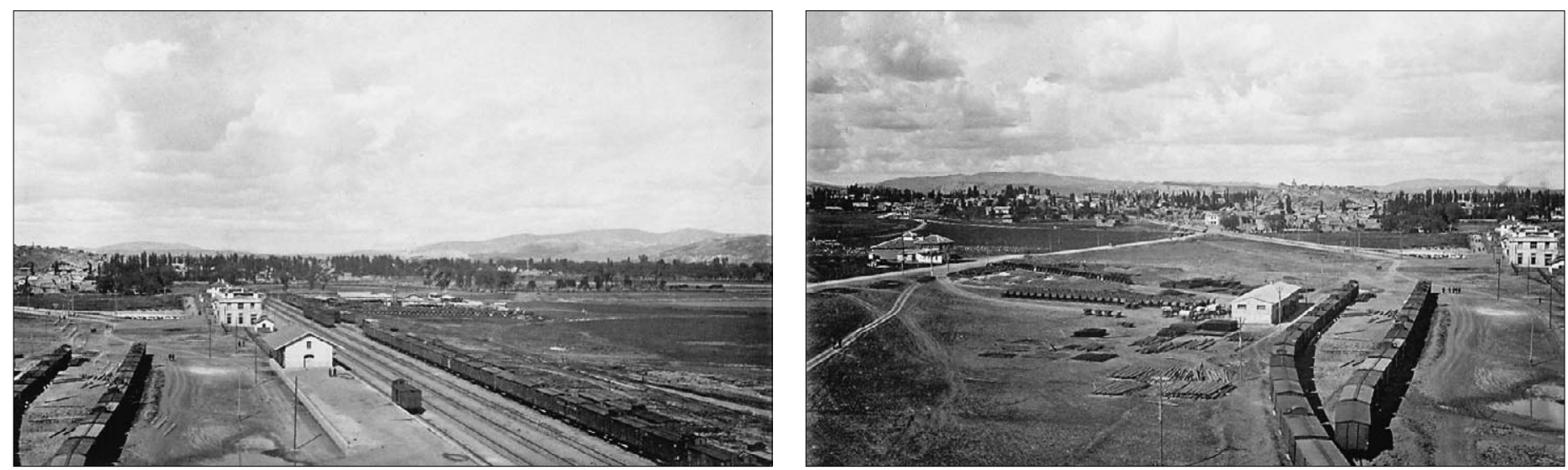

FIG. 2 RAILWAY LINE ON THE WEST SIDE OF THE TRADITIONAL CITY AND OPEN URBAN AREA, KNOWN AS KAYSERIKAPI CEMETERY

SL. 2. ŽELJEZNIČKA PRUGA U ZAPADNOM DIJELU GRADA OTVORENE URBANE ZONE POZNATE POD NAZIVOM KAYSERIKAPI in architecture became visible through new spatial productions (new types of buildings/ typologies). Architectural and urban renewals in the period from the end of the $19^{\text {th }}$ century to the 1930 s on the scale of Sivas were a kind of modernity practice. However, it is difficult to speak of an urban system that is completely disconnected from the spatial structure created by the traditional urban fabric. Such a radical transformation could only be realized on the urban scale when the railway line came to the city. In the city, new topographical and morphological transformations were triggered by the modernization practice of the nation-state and thus, urban areas met sharp and rigid modernism in the 1930s. First of all, railways, which have symbolic status as "contemporary civilization level" for the Republican regime, have been transformed into technical, social and urban innovation lines as a means of civilization in the Sivas scale.

Sivas State Railway Campus is located to the west of the traditional settlement of the city. The area was defined as an open urban area to the west of the city before the construction started; it is also confined to the area where the outer walls of the city known as Kayseri Gate are located and where the Kayserikapi cemetery is located (Fig. 2). This urban area also defined the boundary of the rail network at that time. Today, the Sivas State Railways campus, which is built on an area of 300.000 $\mathrm{m}^{2}$, consists of approximately 180 buildings, and was developed primarily between 1930$1951 .{ }^{17}$ In this process, the construction started in the Kayserikapı cemetery area on the west side of the city with the construction of the station building first. It later became a campus with the articulation of production and social equipment in line with the requirements of the railway network (Fig. 3). The shaping of the urban openness towards the south-east line of the settlement continued with the establishment of the wagon factory (Fig. 4). The railway repair shop (wagon fac- tory), founded in 1939 , is the first stateowned industrial enterprise in Sivas. Even though the railway station and the service buildings of this station were part of a certain industrialization initiative, the urban space faced a stronger industrialization move with the establishment of the railway repair shop as a factory. This means that urban spaces such as the administrative center and the trade center, which continued to function as urban backbone despite the new structure typologies in the traditional settlement until the 1930s, encountered a radical form of urban articulation after this date. Thus, the railway network and railway repair shop have a founding role in marking the western side of the city an industrial zone. This is because the public factory complexes located in an area outside the city and added to this chain by the rail network are characteristic of the early Republican period; these settlements consist of production and storage spaces, public housing, social service and recreation areas with the nature of an integrated and closed colony. ${ }^{18}$

Therefore, it is useful to mention how the railway service buildings and the railway repair shop form the western part of the city on an urban scale. That area was conceived as an openness until the 1930s. The railway campus was first constructed from west to the east, parallel to the railway network, and then, penetrated to the south for the spatial units of the wagon factory. In addition, social units of campus were located to the north of the production units. More specifically, while the railway station and station service buildings provided a construction pattern adjacent and parallel to the railway, at the same time the area is characterized by a spread on the east-west axis. However, over time, especially with the construction of public housing, and after the 1950s, with the addition of equipment such as schools, hospitals, and training centers, the railway campus expanded to the north. As a result, the area of 
Kayserikapı cemetery was destroyed by the constructions. Also, a new artery was created to connect the administrative center, the Government Square, which was reinforced with the administrative mechanism during the Republican period, to the train station; in other words, it was designed to connect the modernity transmitting fiction on the west side of the city. This linear artery, known as Istasyon Street, opened from the railway station to the Government Square and has the task of connecting modernist aesthetics to the traditional fabric of the city. If a parenthesis is opened here, it is a characteristic urban mechanism that connects the railway station and the service buildings around it to the traditional fabric of the city through the railway network, which emerged as a compulsory infrastructure project during this period. Such an artery is a modernist zoning project with its green refuges, segregated fiction of pedestrian and auto traffic, distribution and dimensions of public buildings, and is radically different from the old urban fabric. ${ }^{19}$ The establishment of the Railway Repair Shop led to the transformation of Yukarı Kale and its environs, Yukarı Kale is located to the east of the railway campus. The wagon factory, located to the south of the railway campus, expanded this open area to the west of the city and destroyed the traditional fabric nearby. The State Railway [SRW] campus and Railway Repair Shop are like urban parts that are joined together. In the 1950s, these campuses, which reinforce their existence as the most defining elements of modern urban structure, have become the primary urban dynamics with their campus spatial systems and the typological diversity that displays the stylistic content of modern architecture in a rational setting. This means that the railway campus not only leads to the formation of an industrial zone on the western side of the city, but also acts as a threshold between the traditional fabric of the city and the area where modernism is leaking. As a matter of fact, until the 1950s, the western side of the city defined an urban space reinforced by factories, and after 1950, the same region witnessed the infiltration of public buildings in the form of a campus, especially those in need of large-scale and service-oriented vehicles.

On the architectural scale, it is understood that the most prestigious building among the buildings belonging to the railway campus is the railway station. Sivas railway station includes the characteristic architectural elements of modernist aesthetics such as simple,

\footnotetext{
17 BAyram, Uluşans, 2009: 237

18 BILGIN, 1998: 261

19 BILGIN, 1998: 260
}

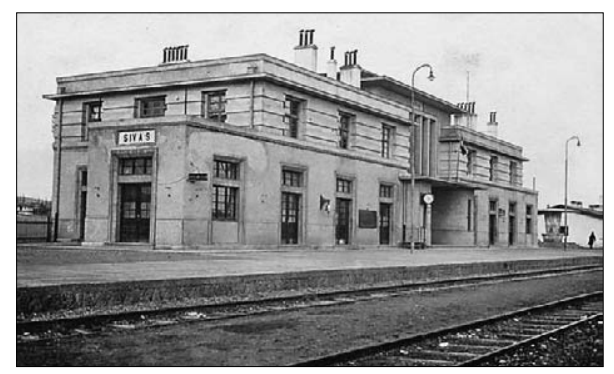

vertical and horizontal volumes, symmetry, a flat roof, and geometric facade composition. Other station service buildings belonging to the campus were constructed with a very functionalist attitude. Although there is a consistent scale between the buildings, there are no stylistic elements that provide continuity for facade systems or planimetric organizations. However, the Railway Repair Shop reveals all the requirements of modern factory space with both functionalist and rationalist systems: a prismatic body, a large span steel truss of the interior systems, roof window elements such as ribbon windows seen in the front string creating Railway Repair Shop. This defining architectural language also refers to a common design approach applicable to factory buildings of the period. Despite the implications of railroads in the modernity experience, the factory is the first large-span space in the city and is the first modern structure that responds to a function that did not previously exist in the city.

\section{TRANSFER OF Public PROgRamS to URBAN SPACE BETWEEN 1930-1950}

\section{PRIMJENA JAVNIH PROGRAMA NA URBANI PROSTOR IZMEDU \\ 1930. I 1950.}

This modern threshold opened by the railway campus and wagon factory on the west side of the city is at the junction point of two arteries which are directed to the east and west, and the artery which opens to the east, Istasyon Street, leads to the traditional settlement of the city. The other artery to the west of the modern threshold formed near the railway station marks the ring road of the city to

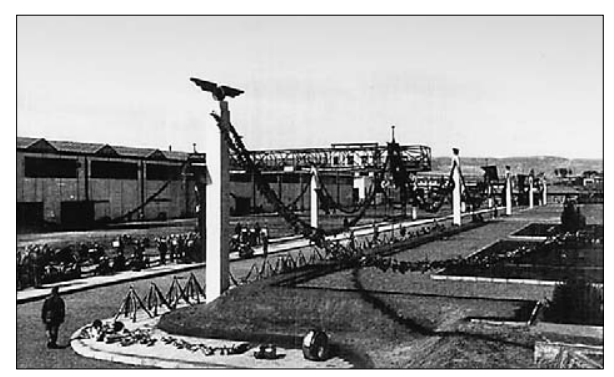

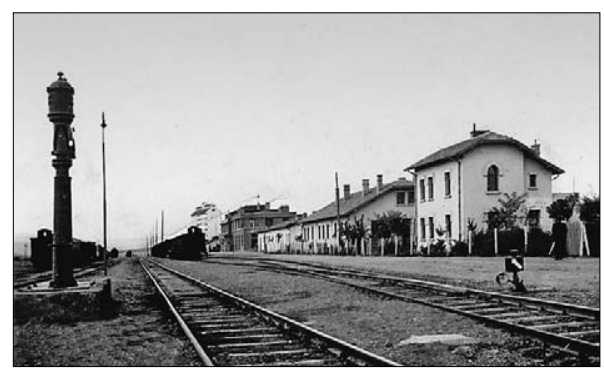

FIG. 3 SIVAS TRAIN STATION AND ITS SERVICE BUILDINGS SL. 3. KOLODVOR U SIVASU S PRIPADAJUCIM ZGRADAMA
FIg. 4 WAgON FACtORY, KNOWN AS CER AtÖLYESI SL. 4. TVORNICA VAGONA POZNATA POD NAZIVOM CER ATÖLYESI

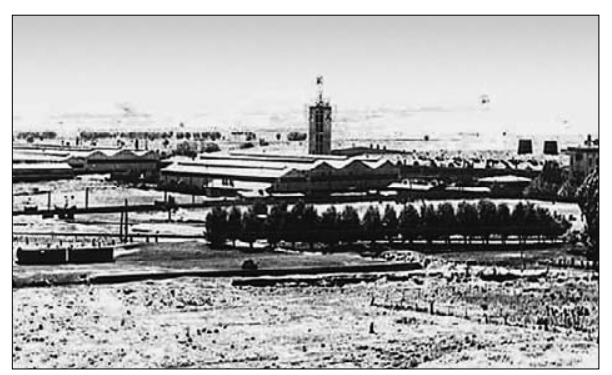




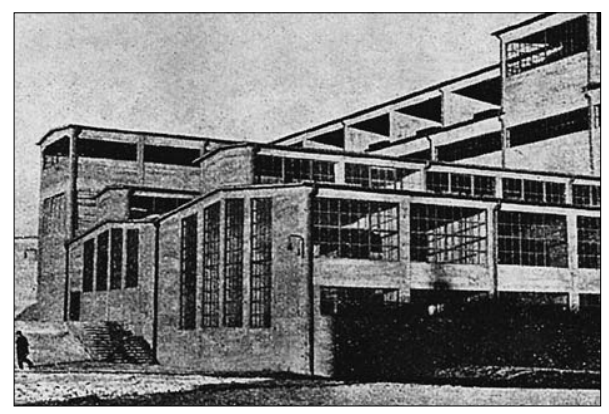

Fig. 5 CEMEnt FACtory SL. 5. TVORNICA CEMENTA

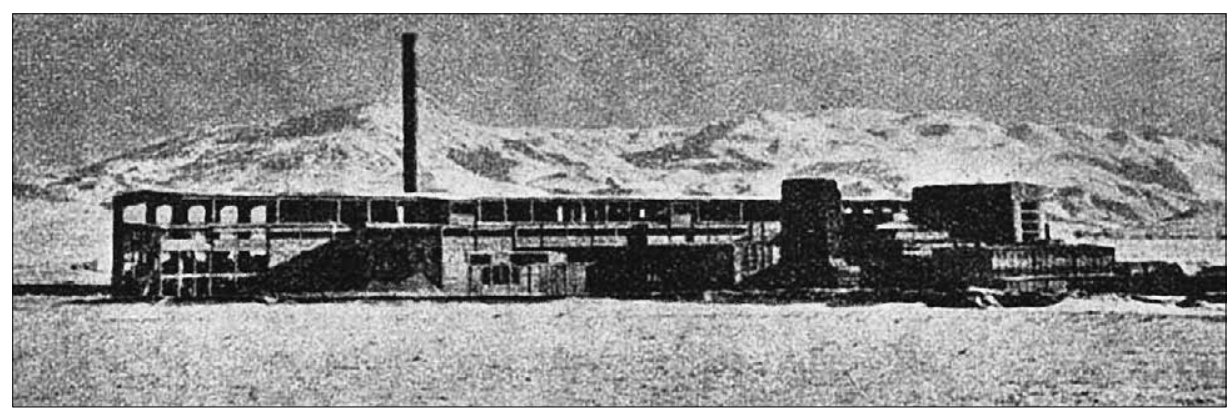

Ankara and this route is called Barbaros Boulevard. Barbaros Boulevard continued to be formed as an artery with two new factory settlements until the 1950 s. During this period, the Cement Factory and Military Sewing House were founded in the region. The $\mathrm{Ce}$ ment Factory was constructed by the German Humbolt company under the direction of Sümer Bank Construction Science Committee. Building began in 1938, was put on hold during the war, and resumed production in 1943. The factory, located on the Ankara-Sivas ring road, marks the last urban part to the west of the city. This means that, as a threshold, the area to the east of the railway campus is dominated by the traditional fabric, and the west of the threshold appears as the main axis of the modernization route.

Sivas Cement Factory, established to meet the cement needs of Central and Eastern Anatolia, which will be used especially in railway construction, is planned as a campus consisting of production and social areas (Fig. 5). There is a small railway station to the south of the settlement which is located on the north line of the Sivas-Ankara highway and the factory is connected to the railway network to the south by narrow gauge railways. In addition to production areas, directorates, laboratory buildings, workers' and officers' houses, a small bazaar, truck and tram garages, a cinema, a cafeteria, a guest house and sports facilities make up the other facilities of the campus. ${ }^{20}$ Also, among the reinforcements built on the campus under the direction of Sümerbank, there is a school called "Sümer Elementary School" which was active between 1945 and $1998 .^{21}$ In terms of the added value produced by the Cement Factory, in other words, the contribution of easily accessible cement to the city, it has paved the way for new developments in the urban space. This production output on the axis of construction material changed the vocabulary of materials and construction techniques of the city. On the one hand, while modern apartment buildings are being built rapidly, traditional form vocabulary started to emerge due to the opportunities offered by cement. The first findings for such a change were obtained from new neighbor- hoods established around factories. More specifically, as cement became an easily accessible material, instead of the traditional construction technique and material, a new construction tradition was created under the formal language of modern architecture by the first social segment of factory workers that migrated from the rural areas to the city. This means that there are architectural elements such as reinforced concrete, singlestory, single-family houses in the Altıntabak District which constitute the first scale of slums on the west side of the city. Thus, the Cement Factory, in terms of its production mission, technical content, and the social mechanism it defines, has kept the western exit of the city as a highly planned pattern. With the Cement Factory at one end and the railway station and wagon factory at the other, Barbaros Boulevard has become an urban space in which the economic progress of the early Republic period was realized. At the same time, through the social facilities they define, these two settlements caused the city to receive immigrants thanks to the employment opportunities created while establishing the codes of conduct of modernization.

Another factor that triggered migration from rural areas to the city is the Military Sewing House, established in 1945 in the northwest of the railway campus. The Sewing House, which was planned as a campus, was planned with multiple spatial integrity with production-service units, sports, and storage areas. Although the Sewing House does not offer any public housing construction, it will trigger the formation of the officers' houses and the Altintabak District, which, in time, will form the Barbaros Boulevard. While the rational architectural elements starting from the reinforced concrete eaves of the campus can be read in all storage areas and service units, the main mass of the factory is defined by a local classicism.

Thus, at the end of the 1930s, the settlement, which was marked as the industrial zone of the city, turned into a region where a group of

\footnotetext{
$20 * * \star$ 1944: 195; KAPLAN, 2009: 372

21 KAPLAN, 2009: 372
} 
workers clustered in the city and led to the opening of residential areas around the factories. The train station, which consists of multiple spatial units and extends to large urban parts; station service buildings, a wagon factory, sewing house and cement factory around the beginning of a scale that can be called the settlement of the inhabiting movements, have emerged. These new residential areas emerged initially on a scale that could be called slums, and shaped the built environment with a low density, gardenlike, and detached appearance within the urban space. The factories, which emerged in the form of campuses until the $1950 \mathrm{~s}$, created a preparatory-constructive effect for the transfer of public patterns of the area, which were planned after 1950 with multiple spatial units. Parallel to this, the development of Barbaros Boulevard and the Altıntabak District just north of the city was accelerated by the cooperatives built after 1950 .

Contrary to the fact that the artery to the west of the railway station was shaped by factory settlements as the threshold of modernization, the artery to the east of the railway network was reported to have penetrated the traditional fabric of the city. It is necessary to state here that public buildings, which were articulated to Sivas between 1930 and 1950 and were the face of the state organization, permeated mostly in areas such as administrative centers or trade centers. In these congested areas, modernist aesthetics leaking into the traditional fabric of the city presents a single-scale and stand-alone architectural program. Significant elements of public buildings in Ankara, such as flat roofs, plain surfaces, curbs around outer windowsills, and high colonnades, were transported into the traditional urban fabric in Sivas. The first transmitter of the classicism of the local scale was the PTT building, and despite its monu-

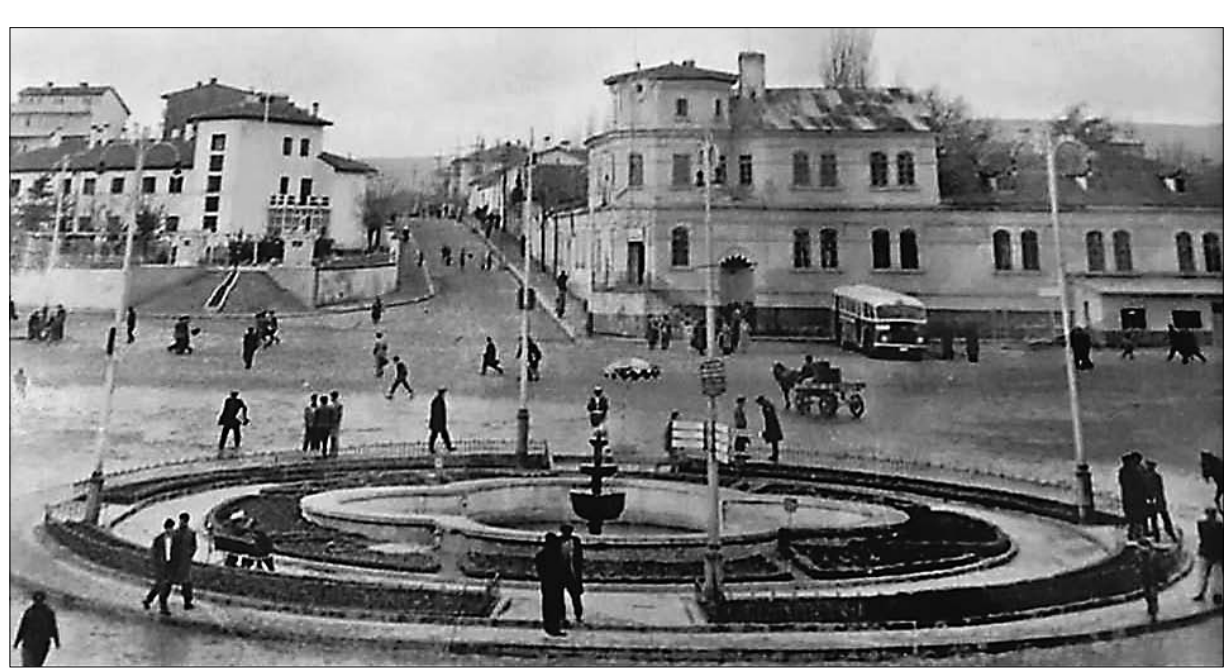

mental classicism or positional dominance over the governing center, it did not create a rapid transformative effect in the urban space (Fig. 6). It can be claimed that the PTT building, located at the intersection of Government Square, which is the administrative center, and Atatürk Street, which defines an important route of the commercial center, transforms only the traditional bazaar center with new building typologies built on a single building scale. With the counterline of the PTT building, namely Bankalar Street and Municipal Park on the western side of Atatürk Street, a program of reconstruction has emerged on this traditional fabric. The most characteristic buildings of this area are İş Bank, Emlak Kredi Bank and Municipal Wedding Hall buildings which are located adjacent to a linear axis on Bankalar Street. Constructed in a single structure with a congested traditional texture, these buildings maintained a local classicism in urban spaces until the 1960 s with their prismatic bodies, colonnaded ground floor surfaces, and simple facades. The Officer's Club (Orduevi) building, which was built in 1940, stands as the first modern public building among the buildings surrounding the Government Square (Fig. 7). The Officer's Club, which consists of several buildings in a large garden, does not have the appearance of a full campus, but the main structure that surrounds the north of the Government Square is realized with a tragic representation in the urban space. The Officer's Club building, which is located just west of the 1908 Gendarmerie Office building, refers to the corner tower of the L-shaped Gendarmerie building with its tower-shaped configuration on the east end of its mass and is reminiscent of the tower-shaped mass organizations seen in public ern side of the railway network, a rational transformation took place only on Istasyon Street, which offers an image of urban space, buildings in Ankara. In the area on the east-

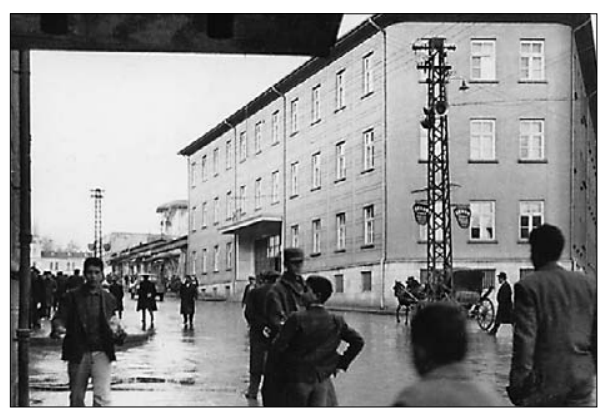

FIG. 6 PTT BUILDING SL. 6. PTT ZGRADA

Fig. 7 OfFicer's Club (ORduevi) BUILding SL. 7. ZGRADA ĆASNIČKOG KLUBA (ORDUEVI)

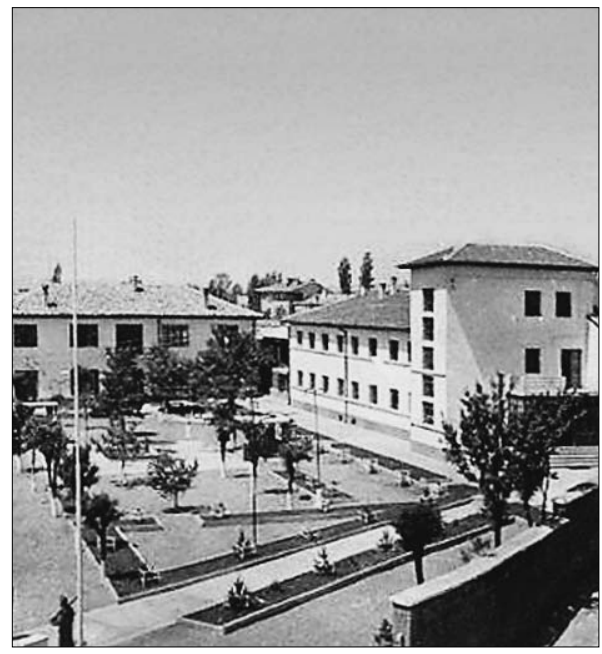




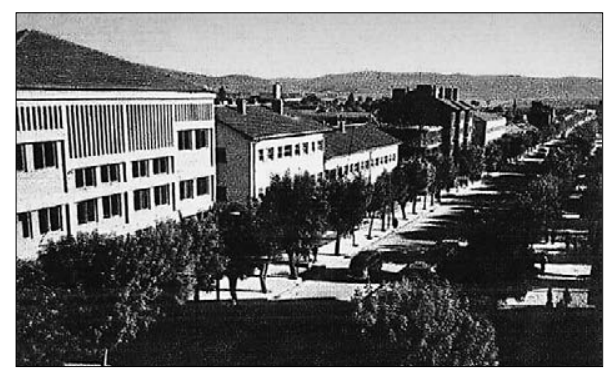

Fig. 8 Esen Cinema, Tekel (inhisarlar) Department and Sivas High SChool Pension in IStasyon Street Sl. 8. Kino Esen, Odsjek Tekel (Inhisarlar) I Sivas High SCHOOL PENSION U Ulici ISTASYON

FIG. 9 GIRLS' Vocational HIGH SCHOOL SL. 9. STRUKOVNA DJEVOJAČKA ŠKOLA

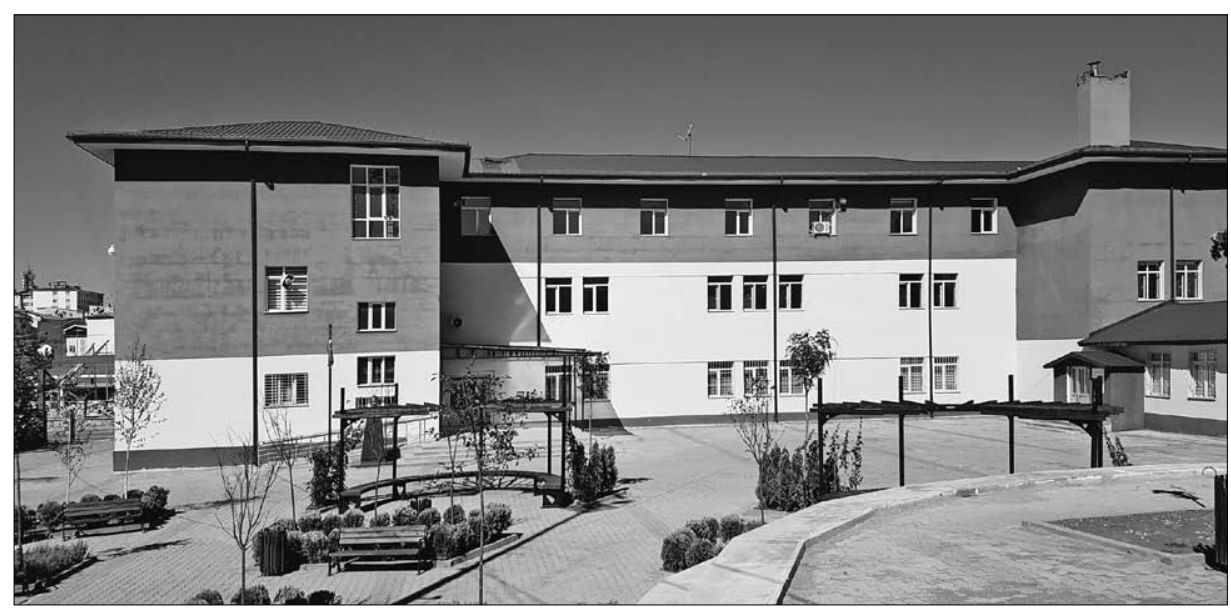

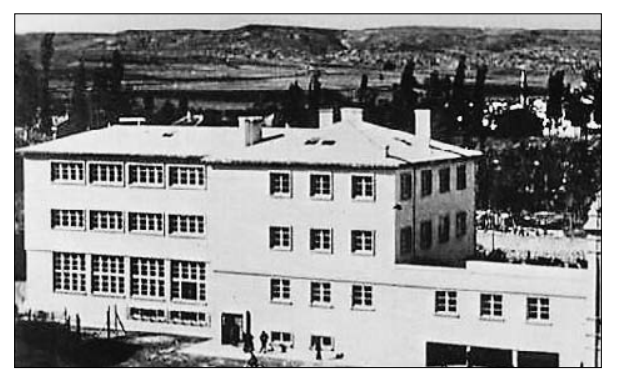

the majority of which was reinforced by apartment buildings. Despite the images such as Esen Cinema, Tekel (İnhisarlar) Department, Sivas High School Pension, and the railroads that shape the western end of the artery, there is no holistic transformation in this traditional part of the urban space (Fig. 8). The west of the railway network, however, under the leadership of the factories, emerged as a new urban pattern articulated in campus form with the axis of Barbaros Boulevard, production, and social equipment.

The only exception, in which the modernist aesthetics were leaking into the traditional fabric in the 1930s through the 1950s, emerged from a single building scale and turned into a campus appearance, can be considered as schools that emerged on the axis of Kepenek Street towards the northeast of Government Square (Fig. 9). The construction started with the construction of Fevzipaşa Primary School in 1938 and resulted in the clustering of school buildings together to form a campus. With the articulation of structures such as Girls' Vocational High School and Atatürk Anatolian High School within the same urban part, the area had become a mechanism formed with the landscape pattern. These structures have been transferred to the traditional fabric with the definition of green areas consisting of large ceremony areas in front of the school buildings, a wooded area, and a pool. It is useful to assess this formation in the more eastern part of the city. Contrary to modernist aesthetics, which can infiltrate the congested areas of the city like PTT building on a singular scale, modern public buildings are initially singular on the northern and eastern lines of the urban space where the traditional fabric is looser; as a result of the loose arrangement of the settlement fabric, a functional and educationaloriented unity was created by combining it with a landscape pattern.

When we talked about the gradual clustering of school buildings in the urban setting, it should not be ignored that the urban space articulation of another educational campus, developed in contrast to this situation. Located on Rahmi Günay Street in the northeast of the Government Square, this campus is the Industrial Vocational High School campus, which was transferred to the urban part where the industrial school and ironworking atelier was built in the early $20^{\text {th }}$ century. The campus consists of classrooms, a casting department, an engine compartment, an electrical and electronics department, a furniture workshop, a metal workshop, a model workshop, a sports hall, a boiler room, and public housing. All buildings were designed with a rational axis layout between 1940 and 1960. Contrary to the multiple school structures in the school district, the buildings of the Industrial Vocational High School can be regarded as the first multi-unit campus that comes together under a single roof within the traditional fabric.

\section{The Effectiveness of Public SETTLEMENTS AND THE DEFINITION OF URBAN SPACE FROM 1950 TO $1980 \mathrm{~S}$}

\section{JAVNA NASELJA I DEFINICIJA GRADSKOG PROSTORA IZMEDU 1950. I OSAMDESETIH GODINA 20. STOLJEĆA}

It must be said from the outset that disengagement was detected between the first 25 years of the Republic and the second 50 years. ${ }^{22}$ For example, in the urbanization process of 1960-1980, the tendency to build various public service buildings on campuses increased and accordingly, instead of the growth of cities with the addition of individual structures, a growth was formed by adding large parts to the city. ${ }^{23}$ If this situation is studied in the Sivas scale, it can be assumed that an industrial zone emerged on the western side of the city in the 1930-1950 interval

$\begin{array}{ll}22 & \text { BILGIN, 1998: } 257 \\ \mathbf{2 3} & \text { TEKELI, 2009: } 124 \\ \mathbf{2 4} & \text { BOYSAN, 2010: } 83\end{array}$ 
and that this area was equipped with factories and defined a threshold in the urban space. Since the western side of the threshold defines a scale which can be grasped as a void, a more rational mechanism has been used for the emergence of new settlement areas. For example, as can be seen in the city's current plans, this area on the western side of the city is reinforced by a grid system neighborhoods developed around the factories. Therefore, after 1950 , due to the changing political climate and socio-economic conditions, the settlements belonging to the provincial organizations of the public institutions in need of wider openings emerged in this region which has hollow areas. One reason for the emergence of provincial organizations in this area can be shown as having institutions that serve the roads between rural areas or cities and that require fieldwork, rather than institutions that serve the urban space such as education or health. The campuses belonging to the $16^{\text {th }}$ Regional Directorate of Highways in 1966, the Regional Directorate of Soil and Water in 1967 , and the $19^{\text {th }}$ Regional Directorate of State Hydraulic Works in 1976 were located on the west side of the city.

With the beginning of the Menderes period, an intensive investment was made to connect the national market with motor vehicles, and for this purpose, the General Directorate of Highways was established in $1950 .{ }^{24}$ This highly prestigious public institution emerged as a provincial organization in Sivas. The $16^{\text {th }}$ Regional Directorate of Highways was transferred to Barbaros Boulevard in two separate parts with administration, service buildings, and public housing units (Fig. 10). The first part is located in the urban space to the west of the old 4 Eylül Stadium, which is north of the boulevard and is now equipped with highways and guesthouses. The second part is located about 2 kilometers away from the southern line of the boulevard and there are administrative buildings and service units in this area. The focal structure of the campus is the administrative building and the building has a distinctive architectural language especially in terms of its facade character. Thus, during 1960s, Barbaros Boulevard formed a strong public backbone with the 4 Eylül Stadium, Directorate of Highways' public houses to the west of the stadium, Sewing House to the northwest of the houses, and officer houses built to the south of Sewing House and west of the public housing.

The public backbone, defined by the settlement of the highways on the north and south line of the Barbaros Boulevard axis, was completed with the Soil-Water Regional Directorate building located directly opposite the officer's houses. The Soil-Water Regional Directorate is surrounded by the state railway campus in the east. The building, which was built in 1967, has the appearance of a small public campus with its technical units in the backyard, and was used as the Directorate of Rural Services temporarily.

The $19^{\text {th }}$ Regional Directorate of State Hydraulic Works is another public campus situated on the same axis. The campus, consisting of the service building, technical units, and public housing units, will once again assert itself as the public backbone on the western side of the city with an organization similar to the 16th Regional Directorate of Highways; this time the transformation is evident via the architectural language of the buildings. For example, the administrative building, the most prestigious structure of the $16^{\text {th }}$ Regional Directorate of Highways, rises from a large podium on the ground, framing the building mass and emphasizing the entrance line. Again, the inwardly drawn formal arrangement leads to the entrance with a colonnaded system. On the other hand, in the administration building of the $19^{\text {th }}$ Regional Directorate of State Hydraulic Works, there is a more stylized version of
FIg. 10 Some BUILDINGS OF $16^{\text {TH }}$ Regional DiRECTORATE OF HIGHWAYS CAMPUS

SL. 10. Zgrade 16. Regionalne uprave Za CESte
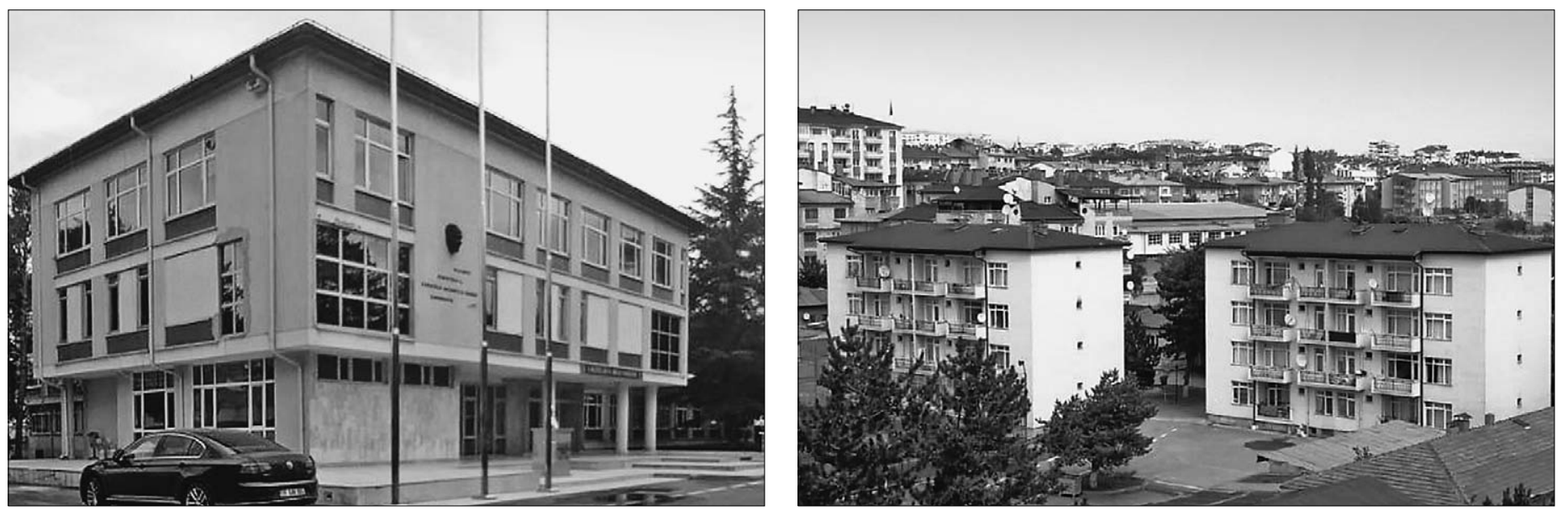


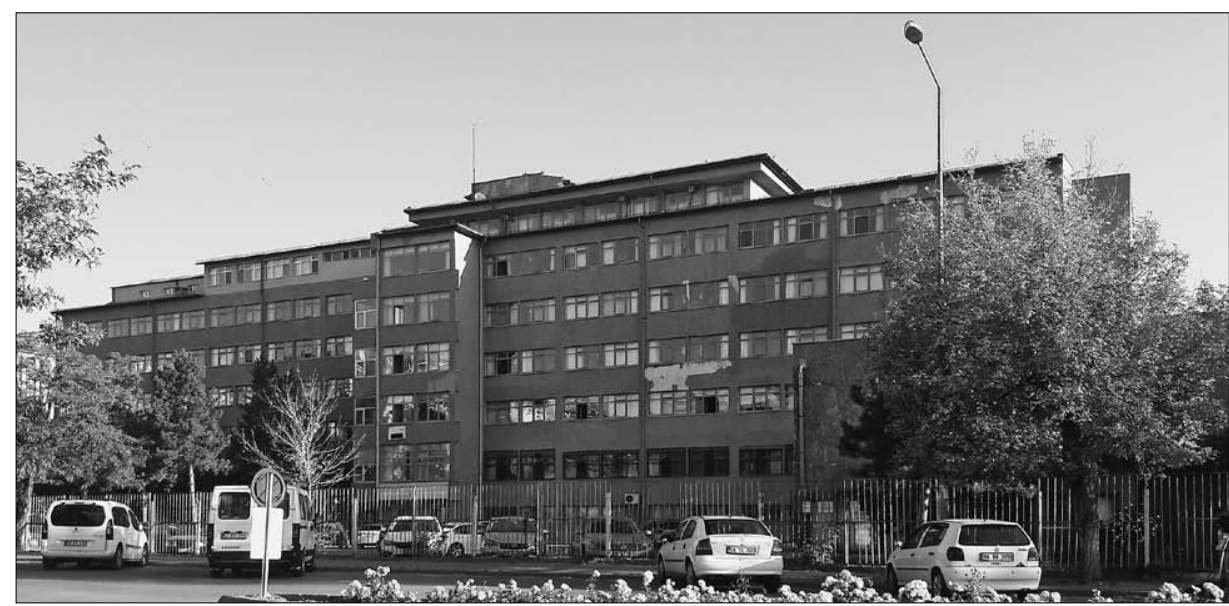

FIG. 11 WORKER'S INSURANCE HOSPITAL IN ISTASYON Street

SL. 11. BOLNICA RADNIĊKOG OSIGURANJA U ULICI ISTASYON

FIg. 12 NUMUNE HOSPITAL

SL. 12. BolniCA NUMUNE

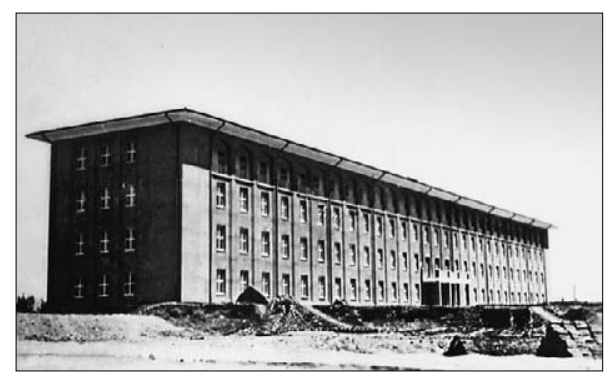

1970 aesthetics. The lightly overhanging and angled composition of the pavements between the floors and the thick and flared eaves circulating the entire mass along the roof level reflects the style of the period.

Barbaros Boulevard, which was consolidated through public campuses until the 1970s, welcomed the 1980 s with a new factory. Established in 1976 under the Ministry of Transport, the Concrete Sleeper Factory, which started production in 1979, is located on the artery after crossing the State Hydraulic Works campus and on the opposite line of the Cement Factory. In this area, falling on the south line of Sivas-Ankara highway, the factory is located adjacent to the railway network. In addition to these public settlements along the western axis of the State Railways Campus, the observatory is another public structure that dates back to the SRW hinterland. A new route parallel to Barbaros Boulevard and Istasyon Street became evident in the 1950s, especially with the expansion of the railway workers' hospital and housing units to the north. The observatory is on this new axis, which is named Halil Rıfat Paşa Street and is dated 1958.

Three important public settlements emerged after 1950 in the east of the SRW Campus. The first of these settlements were on Istasyon Street, which connects to the traditional center of the city. The building and public housing, which served as the Worker Insurance Branch Building, is located on the southern axis and the central axis of Istasyon Street. The insurance institution and lodging buildings, which were built in 1965, are unique examples, especially in terms of cassette facade layout. In 1971, the Worker's Insurance Hospital was built to the west of this public structure (Fig. 11). Consisting of 4 blocks, and a functional-spatial arrangement organized with rectangular masses, all facade surfaces of the hospital were completed plainly.
Numune Hospital is the most prestigious and earliest of the urban settlements leaking into the traditional fabric. Built on Rahmi Günay Street, Numune Hospital is a very important example of modern architecture with its large mass, which can be viewed even from Government Square; the facade defines a monumental classicism and the layout of the urban space with a landscape arrangement (Fig. 12). The Hospital, which was opened in 195253 , opens up the area as a construction site. It can be said that Rahmi Günay Street, where the hospital building is located, is the first artery of the city that began to modernize through westernization reforms. Moreover, it can be said that the first housing cooperative in the city is located in the same area. Teacher Houses built in the 1940 s and this civil collective housing initiative was not carried out by the state. Although Teacher Houses were gradually demolished between 1960-1970; the area of the Numune Hospital Campus continued to be encircled by two new public buildings: the Kızılırmak School in 1954 and the Public Education Center in the 1960s. This means that the Numune Hospital as a public campus shapes the area where it is located and allows for the formation of coherent urban fragments encircled by modernism.

Finally, we will talk about a public settlement outside the prominent arteries such as Barbaros Boulevard, Istasyon Street, Government Square, and Rahmi Günay Street which is not defined by any modernity axis. There is a cemetery consisting of groves near the urban area known as the "Yukarı Tekke". ${ }^{25}$ This area, known as Eğrikavak cemetery, was allocated to village services as a provincial organization after which the cemetery was removed and the area became a small campus. Village Services institution was founded in 1984 with administrative and service units (Fig. 13). As a result, all of these public buildings, constituted as a campus, are important in terms of attracting civil servants and workers' housing cooperatives to the immediate vicinity.

\section{CONCLUSION}

\section{ZAKLJUČAK}

In a wider context, modern architecture and Modern Movement correspond to modernity conditions. Modernism is accepted as a synchronic narrative within the Eurocentric narratives. However, modern history of the nonEuropean countries can be assumed to be diachronic. In this regard, Turkey experienced modernization by the nation-state concept. Ankara as the capital city serves as a model for other Anatolian cities. Although similar urban transformations emerged after

25 ÜREDI, 2006: 230 
the 1930 in Turkey, Sivas experienced modernization practice artificially. What makes Sivas important in this period is that public buildings of the nation-state were transferred to urban space and this caused spatial changes and revealed a traditional-modern dilemma.

The Modernism period in Sivas, between $1930-1980$, is notable for its powerful spatial pattern which articulated the urban texture. Although Sivas began to experience modernization artificially, the urban texture changed rapidly. In particular, public buildings, factories and public campuses have caused spatial organizations of the city to comprehensively renew due to the dominant spatial character of publicness. On an urban scale, public buildings and their campuses accommodate clues of modern architecture and also, have a functional structure in terms of internalization of modernism. On the other hand, the penetration of these spatial organizations in urban space constitute defined spatial elements in their immediate vicinity. Penetration strategy of public buildings and campuses have an architectural attitude as well as modernism's stylistic features. On an urban scale, this penetration strategy leads to the deformation of traditional urban texture. In the period from 1930-1950, public buildings in Sivas, except for factories, were often included in the traditional fabric with singular scale building programs.

In addition to this, modernization through public buildings and campuses in Sivas created new areas in the urban texture. The architectural organizations of these campuses have a subjective attitude toward Sivas in terms of spatial clustering. Articulation types of these modern buildings have a linear configuration and they affect the content of the urban texture in their immediate vicinity. For example, transformations have been experienced thanks to the urban dynamics that

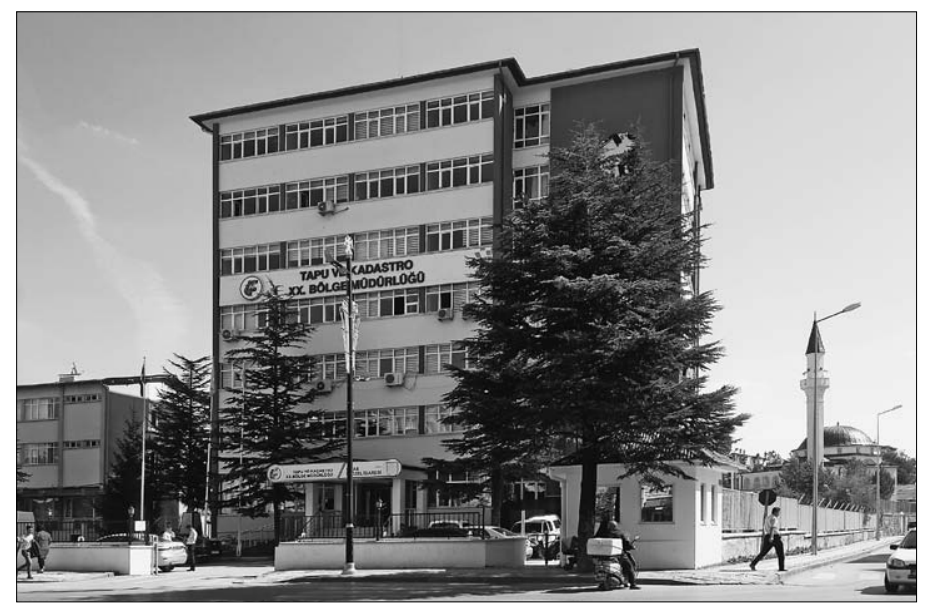

emerged on the western side of the city. At first, factories with their campuses triggered settlement movements on the west side of the city. Eventually, the axis between the railway station and the Cement Factory became the backbone where the public buildings, especially campuses, are located. The strong urban structure, which has existed on the western side of the city since the $1960 \mathrm{~s}$, is a sign that modernization practice is now internalized. This backbone will continue to be equipped with the provincial organizations of the public buildings which were also campuses until the 1980 . Thanks to this public activity, resettlement movements have increased in the immediate surroundings; especially through the slums and the cooperatives, housing density increased and the city morphology expanded to the south and west. As a result, public buildings and campuses in Sivas contribute to the definition of modernism and provide a living modernist aesthetic.

[Written in English by the author, proof-read by JACQUELYN COIRO, Yozgat Bozok University, Turkey]
Fig. 13 Village SERVICES INSTITUtion SL. 13. SEOSKI SERVISI 


\section{BIBLIOGRAPHY}

LITERATURA

\section{SOURCES}

\section{|ZVORI}

1. AkPinar, İ.Y. (2010), Sunuş, in: Osmanlı Başkentinden Küreselleşen Istanbul'a: Mimarlık ve Kent [ed. AkPınar, İ.Y.], Osmanlı Bankası Arşiv ve Araştırma Merkezi: 7-19, İstanbul

2. Batuman, B. (2017), Mekan, Kimlik Ve Sosyal Çatışma: Cumhuriyet'in Kamusal Mekanı Olarak Kızılay Meydanı, in: Ankara'nın Kamusal Yüzleri Başkent Üzerine Mekan-Politik Tezler [ed. SARGIN, G.A.], İletişim Yayınları: 41-76, İstanbul

3. BAyram, G.; Uluşans, G. (2009), Sivas Gar Yerleşkesinin Endüstriyel Miras Olarak Korunması Ve Değerlendirilmesi, in: Cumhuriyet Döneminde Sivas Sempozyumu Bildirileri [ed. Anonymous], Sivas Valiliği Il Kültür ve Turizm Müdürlüğü Yayını: 237-258, Sivas

4. Berkes, N. (2002), Türkiye'de Çağdaşlaşma, Yapı Kredi Yayınları, İstanbul

5. Berman, M. (2017), Katı Olan Her Şey Buharlaşıyor, Trans. Ü. Altuğ ve B. Peker, İletişim Yayınları, İstanbul

6. BILgIn, İ. (1998), Modernleşmenin Ve Toplumsal Hareketliliğin Yörüngesinde Cumhuriyet'in Imarı, in: 75 Yılda Değişen Kent ve Mimarlık [ed. SEY, Y.], Türkiye İs Bankası Kültür Yayınları ve Tarih Vakfı Ortak Yayını: 255-272, İstanbul

7. Boysan, B. (2010), Istanbul'un Sıçrama Noktası, in: Osmanlı Başkentinden Küreselleşen Istanbul'a: Mimarlık ve Kent, 1910-2010 [ed. AKPINAR, i.Y.], Osmanlı Bankası Arşiv ve Araştırma Merkezi: 81-95, İstanbul

8. BozdoĞAn, S. (1999), Türk Mimari Kültüründe Modernizm: Genel Bir Bakış, in: Türkiye'de Modernleşme ve Ulusal Kimlik [ed. BozDoĞAN, S.; KASABA, R.], Tarih Vakfı Yurt Yayınları: 118-135, İstanbul

9. BozdoĞAn, S. (2008), Modernizm ve Ulusun Inşası Erken Cumhuriyet Türkiyesi'nde Mimari Kültür, English Edition: Modernism and Nation Building Turkish Architectural Culture in the Early Republic, Metis Yayınları, İstanbul

10. BozdoĞAn, S.; AKCAN, E. (2012), Turkey Modern Architectures in History, Reaktion Books, London

11. Cengizkan, A. (2009), Sonuç Yerine... Işçi Konutlarında Barınma: Yaşam, Kültür Ve Kentleş- me, in: Fabrika'da Barınmak Erken Cumhuriyet Dönemi'nde Türkiye'de Issçi Konutları: Yaşam, Mekan ve Kent [ed. Cengizkan, A.], Arkadaş Yayınevi: 255-272, Ankara

12. Coluins, P. (1998), Changing Ideals in Modern Architecture, Second Edition, McGill-Queen's University Press, Montreal\&Kingston, London, Ithaca

13. Frampton, K. (1992), Modern Architecture, A Critical History, Third Edition, Thames and Hudson, London

14. Gülalp, H. (1999), Türkiye'de Modernleşme Politikaları Ve Islamcı Siyaset, in: Türkiye'de Modernleşme ve Ulusal Kimlik [ed. BozdoĞAN, S.; KASABA, R.], Tarih Vakfı Yurt Yayınları: 43-53, İstanbul

15. JenCKS, C. (1985), Modern Movements in Architecture, Second Edition, Penguin Books, England

16. KAPLAN, H. (2009), Cumhuriyet Döneminin Ikinci Büyük Yatırımı: Sivas Çimento Fabrikası, in: Cumhuriyet Döneminde Sivas Sempozyumu Bildirileri [ed. Anonymous], Sivas Valiliği İl Kültür ve Turizm Müdürlüğü Yayını: 365-378, Sivas

17. Sargin, G.A. (2017), Kamu, Kent Ve Politika, in: Ankara'nın Kamusal Yüzleri Başkent Üzerine Mekan-Politik Tezler [ed. Sargın, G.A.], İletişim Yayınları: 9-40, İstanbul

18. TEKELI, İ. (1998), Türkiye'de Cumhuriyet Döneminde Kentsel Gelişme Ve Kent Planlaması, in: 75 Yılda Değişen Kent ve Mimarlık [ed. Sey, Y.], Türkiye İş Bankası Kültür Yayınları ve Tarih Vakfı Ortak Yayını: 1-24, İstanbul

19. TEKELI, İ. (2009), Modernizm, Modernite ve Türkiye'nin Kent Planlama Tarihi, Tarih Vakfı Yurt Yayınları, İstanbul, ISBN: 978-975-333-234-7

20. ÜREDI, K. (2006), Bir Şehrin Beş Hali, Ötüken Yayınları, İstanbul

21. ZüRCHER, E.J. (2002), Modernleşen Türkiye’nin Tarihi, Trans. Y.S. Gönen, İletişim Yayınları, İstanbul

22. *** (1944), Sivas Çimento Fabrikası, “Arkitekt”, 9-10: 195-197, İstanbul

\section{ILLUSTRATION SOURCES}

IZVORI ILUSTRACIJA

FIG. 1 Author, 2020

FIG. 2-3, 12 sivasresimleri, 2018. http://www.sivas.li [25.8.2018.]

Fıg. 4 Önemlibıçak archive, 2018. Erdoğan Önemlibıçak personal archive

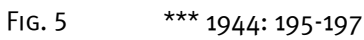

FIG. 6 sivasresimleri, 2018. http://www.sivas.li [25.8.2018.]

FIG. 7 birzamanlarsivas, 2018. https://www. facebook.comsivasbirzamanlarsivasphotos [11.9.2018.]

Fıg. 8 Önemlibıçak archive, 2018. Erdoğan Önemlibıçak personal archive; sivasresimleri, 2018. http://www.sivas.li [25.8.2018.]

FIG. 9-11, 13 Author, 2018 


\section{SUMMARY}

SAŽETAK

\section{ANALIZA ARHITEKTURE MODERNE NA PRIMJERIMA JAVNIH ZGRADA U SIVASU}

Proglašenjem Republike 1923. godine Turska je kao nacionalna drżava krenula putem modernizacije. Tražeci načine kako unaprijediti tehnički i ekonomski razvoj, utemeljitelji Republike slijedili su razvojni put modernizacije društva. Moderna se u tom procesu pojavila kao prikladan alat. $\mathrm{S}$ jedne su strane razvojne inicijative ostvarene osnivanjem modernih tvornica u zemlji i uspostavom żeljezničke mreże. A s druge je strane moderna utjecala ponajprije na arhitekturu i stil żivota u Ankari, a poslije i u ostalim anatolijskim gradovima. Tako su nastale javne zgrade i stanovi izgrađeni u duhu moderne kao alternativa tradicionalnomu urbanom tkivu. Nakon Drugoga svjetskog rata, zajedno s politikom liberalizacije u Turskoj, kontekst modernizma promijenio se u pogledu gradskog prostora. Modernistička klima koja se razvila zbog arhitektonskih i urbanističkih intervencija prije 1950. omogucila je pripremnu infrastrukturu za artikulaciju novih urbanih dijelova u kojima je urbano mjerilo došlo do izražaja nakon 1950 . godine.

Ovaj se rad bavi praksom modernizacije u kontekstu grada Sivasa. Glavni je cilj analize ispitati intervencije na gradskoj periferiji kroz prostornu dinamiku koju su potaknule tvornice izgrađene $u$ ranom razdoblju Republike, kao i trendovi ponovnog naseljavanja tih prostora u gradu Sivasu. Prije 1950. javne su se zgrade u Sivasu gradile fragmentarno i pojedinačno. No, nakon 1950. došlo je do racionalnog pristupa planiranju, sto je povezano također s promjenom načina razumijevanja ovih procesa.

Nakon 1950. javne su zgrade bile organizirane u formi kampusa, iako su bile definirane specifičnim funkcionalnim programom. Może se reći da su nakon 1950. godine javne građevine u gradovima bile produżetak provincijalne organizacije, kao što su regionalne uprave cesta, pa su pridodane gradu u formi kampusa. U pozicioniranju tih kampusa, SRW kampus predstavlja razdjelnicu između istočnoga $i$ zapadnoga dijela grada.

Glavna moderna arterija, kao što je Ulica Istasyon, nastala je u istočnom dijelu grada, gdje su izgrađene razne javne zgrade. Duž osi Trga Vlade i Ulice Atatürk pojedine su javne zgrade reprezentativni primjeri estetike moderne, primjerice Časnički klub (Orduevi) ili zgrade Emlak kreditne banke. Prve modernističke škole, kao što je osnovna škola Fevzipaşa, prebacene su u rahliju strukturu naselja; imale su svoje parkove i zadobile karakteristicnu formu kampusa pozicioniranjem više od jedne školske zgrade u istome parku duž osi Ulice Kepenek. To se może smatrati prvom etapom estetike moderne u urbanom prostoru. Osobito reprezentativna zgrada iz razdoblja između 50-ih i 60-ih godina 20. stoljeca jest bolnica Numune u Ulici Rahmi Günay, gdje je također smještena $\mathrm{i}$ industrijskostrukovna srednja škola. Bolnica Numune prvi je primjer ublažavanja stroge estetike moderne iz razdoblja prije 1950 -ih godina. Takvi projekti pojavili su se u Ulici Istasyon tek sedamdesetih godina 20. stoljeća. Kampus, izgrađen kao Bolnica radničkog osiguranja, sastoji se od nekoliko jedinica i nalazi se na urbanom prostoru neobiljeżenom pejsażnim uređenjem.

Ovi strukturni programi uslużnih i zdravstvenih jedinica diversificirani su provincijalnom organizacijom novih javnih institucija koje su nastale u promijenjenim okolnostima nakon pedesetih godina 20. stoljeća. Može se reci da su nakon 1950. godine javne zgrade građene putem opseżnih intervencija u gradskom prostoru. Te inicijative u malome mjerilu kampusa odredile su način na koji su se gradile javne zgrade još naglašenijim i dovele do definicije urbanoga mjerila upravo kroz te kampuse. Najrani- ja i najprestiżnija organizacija u takvom procesu jest 16. Regionalna uprava za ceste.

Kampus koji se prostire na velikoj površini sadrži objekte za stanovanje, društvene sadržaje, uslužne sadrżaje i upravnu zgradu u zapadnom dijelu grada. To je prvi javni projekt u razdoblju nakon 1950. godine izgrađen, prvi put nakon tvornica, temeljem državno potpomognutog višestrukturnog programa. Sve javne zgrade i tvornice koje su bile preseljene u urbani prostor, kao što su Opservatorij, Uprava za zemljišta i vode, 19. Regionalna uprava državnih hidrauličkih radova i dr., pojavile su se s drukcijim sadržajem od onoga imidża modernizma stvorenog u nacionalnoj drżavi prije 1950. godine. Kao rezultat toga industrijska je zona u zapadnom dijelu grada, okružena Zeljezničkom remontnom tvornicom, Vojnom tvornicom šivanja i Tvornicom cementa, stvorila dinamiku prakse modernizacije na primjeru grada Sivasa. Nakon 1950. godine to područje postaje okosnica grupiranja javnih zgrada, osobito kampusa. Primjeri kao što su Bolnica Numune ili Bolnica radničkog osiguranja pokazuju da su javne zgrade nakon 1950. planirane kao kampusi. U zapadnom dijelu grada, kao industrijskoj zoni prije 1950. godine, nalazile su se tvornice. U istome su razdoblju moderne javne zgrade utjecale na tradicionalno projektiranje naselja. Primjeri škola i ostalih obrazovnih institucija pokazuju (premda su u početku bile gradene kao individualne zgrade) da dolazi do njihova spontanoga grupiranja, zahvaljujuci lokaciji, u istome urbanom području. Zbog konsolidiranja tvornica i javnih kampusa u zapadnome dijelu grada prvi su gradski ‘slamovi’ nastali oko tvornica i javnih zgrada; gustoca stanovanja povecala se kroz zadruge, a grad se sirio prema jugu i zapadu, dok je dilema u pogledu odnosa tradicionalnoga i modernoga postajala sve očitija u gradskom prostoru.

\section{BIOGRAPHY}

\section{BIOGRAFIJA}

PINAR KoC is an architect and research assistant. She is in her final year of PhD at Necmettin Erbakan University. She graduated from Selcuk University in the department of architecture and received a Master's degree in Architecture at Erciyes University. Her researches focus on modernization practice in Turkey and architectural education. She has published many essays on architectural education, architectural history and theory.
PINAR Koc je arhitektica i znanstvena asistentica. Trenutačno završava posljednju godinu doktorskog studija na Sveučilištu Necmettin Erbakan. Diplomu magistre arhitekture stekla je na Sveučilištu Erciyes. Njezin je istraživački interes usmjeren prema praksi modernizacije u Turskoj i obrazovanju u području arhitekture. Objavila je brojne eseje s temama koje se odnose na obrazovanje arhitekata, te povijest i teoriju arhitekture. 
